\title{
NILAI OBJEK WISATA AIR TERJUN WAY LALAAN PROVINSI LAMPUNG DENGAN METODE BIAYA PERJALANAN (TRAVEL COST)
}

\section{VALUE OBJECT WATERFALL WAY LALAAN LAMPUNG TRAVEL COST METHOD (TRAVEL COST)}

\author{
Jenny Sartika Sihotang, Christine Wulandari, dan Susni Herwanti \\ Jurusan Kehutanan Fakultas Pertanian Universitas Lampung \\ Jl. Soemantri Brojonegoro No.1 Bandar Lampung \\ E-mail : Jeny.sihotang@yahoo.com
}

\begin{abstract}
ABSTRAK
Objek wisata Air Terjun Way Lalaan merupakan salah satu bentuk jasa lingkungan yang kurang berkembang padahal memiliki potensi ekonomi yang cukup baik jika dikelola secara tepat. Oleh karena itu perlu dilakukan penelitian dengan tujuan menentukan nilai objek wisata air terjun Way Lalaan dan mengetahui pengaruh karakteristik pengunjung terhadap biaya perjalanan. Manfaat hasil penelitian digunakan sebagai bahan pertimbangan dalam pengelolaan objek wisata ini ke depan. Penelitian dilakukan pada bulan Maret-April 2013 dengan responden sebanyak 96 orang dengan melakukan wawancara langsung yang diproksi dengan biaya perjalanan pengunjung. Penentuan hasil biaya perjalanan pengunjung akan di di uji dengan menggunakan metode analisis linear berganda dengan software Minitab 16. Hasil penelitian menunjukkan biaya perjalanan pengunjung sebesar Rp.16.284.500 /orang/kali kunjungan, biaya rata-rata perjalanan Rp.203.104 orang/kali kunjungan. Nilai rekreasi sebesar Rp. 487.449.600/ Tahun. Variabel luar Provinsi, umur dan status pernikahan secara simultan mempunyai pengaruh nyata terhadap biaya perjalanan, besarnya nilai simpangan baku (S) adalah Rp.151.589. Besarnya pengaruh variabel dependen secara simultan (R-Sq) adalah $61,9 \%$ dan R-Sq(adj).
\end{abstract}

Kata Kunci: air terjun Way Lalaan, analisis regresi ganda, biaya perjalanan, nilai air terjun

\begin{abstract}
Attraction Waterfall Way Lalaan is one form of environmental services are less developed but has significant economic potential if managed properly. It is therefore necessary to study with the aim of determining the value of the waterfall attraction Way Lalaan visitor characteristics and determine the effect on travel expenses. Benefits of the research results are used as consideration in future management of this attraction. The study was conducted in MarchApril 2013 with as many as 96 respondents with direct interviews with travel costs were proxied visitors. Determination results of visitor travel expenses will be tested using multiple linear analysis with Minitab 16 software.The results showed the cost of travel for visitors Rp.16.284.500/orang/kali visit. The average cost of a trip Rp.203.104 person / visit. Recreational value of Rp. 487449 600/year. Variables outside the province, age and marital status simultaneously have a real influence on the cost of the trip. The value of the standard deviation $(S)$ is Rp.151.589. The amount of influence the dependent variables simultaneously $(R-S q)$ was $61.9 \%$ and $R-S q$ (adj) which means the amount fluctuates depending on the variables influence the correlation of independent variables were added to a dependent variable is equal to $54.8 \%$, while $45.2 \%$ influenced by other variables.
\end{abstract}

Key words: falls value, multiple regression analysis, travel costs, Way Lalaan waterfall 


\section{PENDAHULUAN}

Objek wisata Air terjun Way Lalaan merupakan salah satu objek wisata di Provinsi Lampung, yang secara biofisik wisata ini memiliki potensi wisata alam yang sangat tinggi seperti ekosistem yang masih alami, aksesbilititas yang relatif mudah, letak lokasi yang dekat dengan ibu kota Tanggamus, dan sebagainya. Objek wisata ini semestinya dapat meningkatkan pendapatan asli daerah (PAD) melalui peningkatan aktivitas pariwisata alam, utamanya dapat memikat daya tarik pengunjung dari luar daerah seperti Bandar Lampung, Pringsewu, Lampung Timur dan bahkan di luar Provinsi Lampung dan bahkan manca negara. Harapan tersebut dapat di wujudkan segera, jika sistem pengelolaan objek wisata dapat dikemas dalam bentuk paket wisata yang menarik, peningkatan kegiatan pemasaran, promosi dan informasi kepada publik secara optimal, serta pemenuhan sarana dan prasarana objek wisata sebagai salah satu penunjang ekowisata.

Oleh karena itu diperlukan suatu perbaikan perjalanan yang lebih produktif. Langkah pertama yang diperlukan yaitu tentang nilai objek wisata. Nilai menurut Davis, et, 1987 dalam Alam, dkk., (2009) merupakan persepsi manusia, tentang makna sesuatu objek (sumberdaya hutan), bagi orang (individu) tertentu, persepsi tersebut berpadu dengan harapan ataupun norma-norma kehidupan yang melekat pada individu atau masyarakat. Salah satu pendekatan dalam perhitungan nilai objek wisata adalah dengan menghitung besarnya biaya perjalanan pengunjung objek wisata Air Terjun Way Lalaan.

Tujuan dari penelitian ini adalah menentukan nilai objek wisata air terjun Way Lalaan sekaligus dan mengetahui pengaruh karakteristik pengunjung terhadap biaya perjalanan.

\section{BAHAN DAN METODE}

Penelitian dilaksanakan di obyek wisata Air Terjun Way Lalaan Kabupaten yang berada di Pekon Kampung Baru Kecamatan Kotaagung Timur, Lampung pada bulam Maret-April 2013. Alat yang digunakan dalam penelitian ini adalah kuisioner, alat tulis kantor (ATK), kamera, dan Microsoft office dan Software Minitab 16. Objek penelitian ini adalah pengunjung Objek Wisata Air Terjun Way Lalaan. Metode yang digunakan adalah observasi dan wawancara langsung dengan panduan kuesioner.

Data yang dikumpulkan adalah data primer, diperoleh dari hasil wawancara dengan responden menggunakan kuisioner. Data yang dikumpulkan terdiri dari karakteristik pengunjung meliputi daerah asal, tujuan berkunjung, cara berkunjung, motivasi kunjungan, lama kunjungan, frekuensi kunjungan, dan kondisi sosial ekonomi yang meliputi: umur, jenis kelamin, pendidikan, pekerjaan, pendapatan, waktu luang, jumlah tanggungan, dan status perkawinan yang diperoleh dari hasil wawancara dan kuesioner dari responden terpilih.

Penentuan nilai ekonomi objek wisata Air Terjun Way Lalaan dapat dihitung dengan metode kontingensi, yaitu melalui pendekatan biaya perjalanan, perhitungan biaya perjalanan dapat dilihat dalam Lampiran. Biaya perjalanan dapat dibagi menjadi dua kategori yaitu rasional dan juga dalam bentuk dummy. Bentuk kategorinya dapat di lihat pada tabel 1. 
Tabel 1. Variabel karakteristik pengunjung dan pemberian skor.

\begin{tabular}{|c|c|c|c|}
\hline Variabel Penyebab & Subvariabel Penyebab & $\begin{array}{c}\text { Simbolsasi dalam } \\
\text { Model }\end{array}$ & $\begin{array}{c}\text { Pemberian Skor dan } \\
\text { satuannya }\end{array}$ \\
\hline \multirow[t]{2}{*}{ Zona $\left(\mathrm{X}_{1}\right)$} & 1. Luar Kab & [D1_L.KAB] & Jika ya=1, lainnya 0 \\
\hline & 2. Luar Prov & [D2_L.PROV] & Jika ya $=1$, lainnya 0 \\
\hline \multirow[t]{3}{*}{ Status Pendidikan } & 1. SLTP & [D3_SLTP] & Jika ya=1, lainnya 0 \\
\hline & 2. SLTA & [D4_SLTA] & Jika ya $=1$, lainnya 0 \\
\hline & 3. $\mathrm{PT}$ & [D5_PT] & Jika ya $=1$, lainnya 0 \\
\hline Umur & Umur & [D6_UMUR] & Tahun \\
\hline Pendapatan & Tinggi & [D7_PDPT] & Jika ya=1, lainnya 0 \\
\hline Status Pernikahan & Belum Menikah & [D8_MNKH] & Jika ya=1, lainnya 0 \\
\hline Pekerjaan & Pegawai swasta & [D9_PKRJ] & Jika ya $=1$, lainnya 0 \\
\hline Motivasi & Persinggahan & [D10_MOTIV] & Jika ya $=1$, lainnya 0 \\
\hline Jumlah Tanggungan & Belum ada(0) & [D11_TGGN & Jika ya $=1$, lainnya 0 \\
\hline Jenis Kelamin & Laki-laki & [D12_KLMN] & Jika ya $=1$, lainnya 0 \\
\hline Waktu luang & $>1$ hari & [D13_WKT LG] & Jika ya $=1$, lainnya 0 \\
\hline Jenis Kendaraan & Pribadi & [D14_KNDRN] & Jika ya $=1$, lainnya 0 \\
\hline Jumlah berkunjung & $\geq 2$ orang & [D15_JLH BKJNG] & Jika ya=1, lainnya 0 \\
\hline
\end{tabular}

Sumber : Hasil penelitian (2013).

Uji analisis dengan modul regresi dilakukan dengan menggunakan software Minitab 16. Variabel yang menjadi variabel pengikat $(\mathrm{Y})$ adalah biaya perjalanan dengan karakteristik pengunjung merupakan variabel bebasnya.

Dengan bentuk model Gujarati, (1988) dalam Purwanto (2013)

$$
\begin{aligned}
& Y_{i}=\beta_{0}+\beta_{1}\left[\mathrm{D} 1 \_L . K A B\right]_{\mathrm{i}}+\beta_{2}\left[\mathrm{D} 2 \_L . P R O V\right]_{\mathrm{i}}+\beta_{3}\left[\mathrm{D} 3 \_\mathrm{SLTP}\right]_{\mathrm{i}}+\beta_{4}\left[\mathrm{D} 4 \_\mathrm{SLTA}\right]_{\mathrm{i}}+\beta_{5} \\
& {\left[\mathrm{D} 5 \_\mathrm{PT}\right]_{\mathrm{i}}+\beta_{6}\left[\mathrm{D} 6 \_\mathrm{UMUR}\right]_{\mathrm{i}}+\beta_{7}\left[\mathrm{D} 7 \_\mathrm{PDPT}\right]_{\mathrm{i}}+\beta_{8}\left[\mathrm{D} 8 \_\mathrm{MNKH}\right]_{\mathrm{i}}+\beta_{9}\left[\mathrm{D} 9 \text { PKRJ }_{\mathrm{i}}+\beta\right.} \\
& { }_{9}[\mathrm{JRD}]_{\mathrm{i}}+\beta_{10}\left[\mathrm{D} 10 \_\mathrm{MOTIV}\right]_{\mathrm{i}}+\beta_{11}\left[\mathrm{D} 11_{-} \mathrm{TGGN}\right]_{\mathrm{i}}+\beta_{12}\left[\mathrm{D} 12 \_\mathrm{KLMN}\right]_{\mathrm{i}}+\beta_{13}\left[\mathrm{D} 13 \_\mathrm{WKT}\right. \\
& \mathrm{LG}]_{\mathrm{i}}+\beta_{14}\left[\mathrm{D} 14 \_\mathrm{KNDRN}\right]_{\mathrm{i}}+\beta_{15}\left[\mathrm{D} 15 \_J L H \text { BKJNG }\right]_{\mathrm{i}}+\varepsilon_{\mathrm{i}}
\end{aligned}
$$

Keterangan :

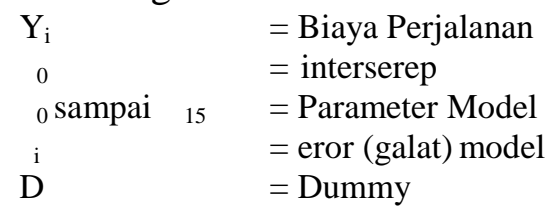

\section{Hipotesis Penelitian}

H0 : Variabel Biaya perjalanan ke objek wisata Air terjun Way Lalaan tidak dipengaruhi secara nyata oleh semua variabel penjelas/ penguji seperti yang dispefikasi dalam model tersebut di atas [Atau: $\left.\beta_{1}=\beta_{2}=\beta_{3}=\ldots \beta_{15}=0\right]$

H1 : Variabel Biaya perjalanan ke objek wisata Air terjun Way Lalaan dipengaruhi secara nyata oleh satu atau lebih dari variabel penjelas/ penguji seperti yang dispefikasi dalam model tersebut di atas [Atau: $\beta_{1} \neq \beta_{2} \neq \beta_{3} \neq \ldots \beta_{15} \neq$ ]

\section{HASIL DAN PEMBAHASAN}

\section{A. Karakteristik Pengunjung}

Hasil dan pembahasan pada data karakteristik pengunjung diperoleh berdasarkan persentase daerah asal, tujuan kunjungan, cara berkunjung, lama kunjungan, motivasi kunjungan, serta kondisi sosial ekonomi yang meliputi: persentase jenis kelamin, umur, tingkat pendidikan, pekerjaan, pendapatan, status perkawinan, jumlah tanggungan, waktu luang, dan jenis kendaraan yang digunakan yang diperoleh dari hasil wawancara yang disajikan pada tabel 2 Fandeli, (2000). 
Tabel 2. Persentase karakteristik pengunjung Obyek Wisata Air Terjun Way Lalaan.

\begin{tabular}{llll}
\hline \multicolumn{2}{l}{ Karakteristik Pengunjung } & \multicolumn{2}{l}{$\begin{array}{l}\text { Jumlah } \\
\text { Pengunjung } \%\end{array}$} \\
\hline & B.Lampung & 48 & 50 \\
& Tanggamus & 18 & 18,75 \\
Zona & Pringsewu & 17 & 17,71 \\
Asal & L. Timur & 1 & 1,04 \\
& L. Utara & 5 & 5,21 \\
& Pesawaran & 2 & 2,08 \\
& L..P. Lampung & 5 & 5,21 \\
\hline Tujuan & Tujuan utama & 43 & 44,79 \\
Kunjungan & Pesinggahan & 53 & 55,21 \\
\hline Cara & Sendiri & 3 & 3,13 \\
Berkunjung & Kelompok & 49 & 51,04 \\
& Rombongan keluarga & 44 & 45,83 \\
\hline Motivasi & Piknik & 74 & 77,08 \\
Kunjungan & Lainnya & 22 & 22,92 \\
\hline Kelompok & $<20$ & 18 & 18,75 \\
Umur & $20-29$ & 53 & 55,21 \\
(Tahun) & $30-39$ & 13 & 13,54 \\
& $40-49$ & 11 & 11,46 \\
& $50-59$ & 0 & 0 \\
& $60-69$ & 1 & 1,04 \\
\hline Jenis & Laki-laki & 66 & 68,75 \\
Kelamin & Perempuan & 30 & 31,25 \\
\hline Tingkat & SD & 3 & 3 \\
Pendidikan & SLTP & 5 & 5 \\
& SLTA & 52 & 54,17 \\
\hline Sumber & PT & 36 & 37,5 \\
\hline
\end{tabular}

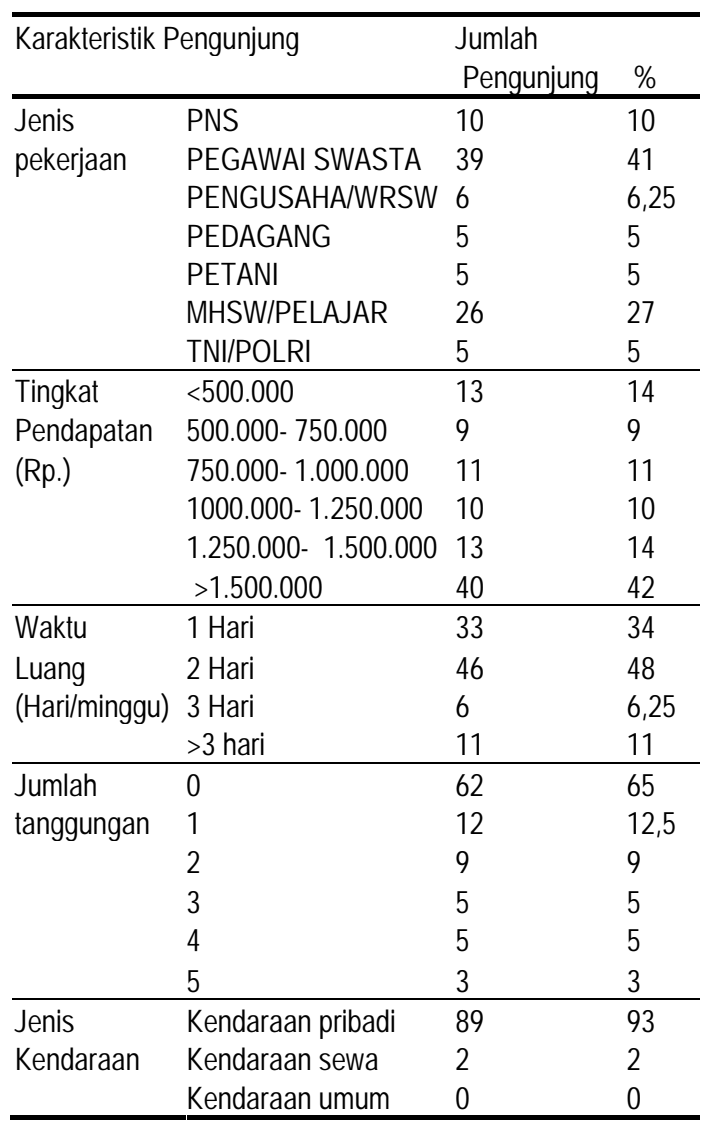

Sumber : Hasil penelitian (2013).

Berdasarkan tabel 2 diketahui karakteristik pengunjung mayoritas berasal dari zona Bandar Lampung sebesar 50\%, sebagian besar sebagai persinggahan yaitu sebesar 55,21\%. Cara berkunjung objek mayoritas berkelompok sebesar 51,04\% dan motivasi kunjungan yang paling banyak adalah piknik sebesar 77,08 \%. Berdasarkan kelompok umur terbanyak adalah dari umur 20-29 sebesar 55,21\%, laki-laki sebagai jenis kelamin paling banyak sebesar $68,75 \%$. Tingkat pendidikan terakhir tertinggi yaitu SLTA sebesar $54,17 \%$. Jenis pekerjaan terbanyak pegawai swasta sebesar $41 \%$. Tingkat pendapatan terbesar adalah $>\mathrm{Rp}$. 1.500.000,00 sebesar 42\%. Berdasarkanwaktu luang terbesar adalah 2 hari yaitu sebesar $48 \%$. Jumlah tanggungan tertinggi adalah responden yang belum memilki tanggungan dan masih tinggal bersama keluarga sebesar $65 \%$, sebagian besar pengunjung menggunakan kendaraan pribadi sebesara $93 \%$.

\section{B. Biaya Perjalanan}

Penggunaan biaya perjalanan menurut teori permintaan, mengatakan semakin tinggi biaya perjalanan maka permintaan akan manfaat wisata semakin rendah. Dalam melakukan perjalanan dari rumah sampai ke objek wisata, pengunjung akan memerlukan biaya-biaya untuk mencapai tujuan rekreasi, sehingga pendekatan biaya perjalanan merupakan salah satu cara untuk menilai suatu barang yang tidak memiliki harga pasar yang dapat memberikan korelasi yang sangat dibutuhkan wisatawan dalam menghitung manfaat suatu objek wisata yang sudah berjalan dan berkembang. Data biaya perjalanan pengunjung dapat dijabarkan dalam bentuk tabulasi.

Berdasarkan hasil penelitian, diketahui bahwa total biaya perjalanan pengunjung ke objek wisata Air terjun Way Lalaan adalah sebesar Rp. 16.248.500/kali kunjungan, dengan 
biaya rata-rata perjalanan sebesar Rp. 203.104 orang/ kali kunjungan. Biaya rata-rata perjalanan tersebut diperoleh, seperti pada gambar 1 .

Biaya Perjalanan pengunjung Objek Wisata Air Terjun Way Lalaan

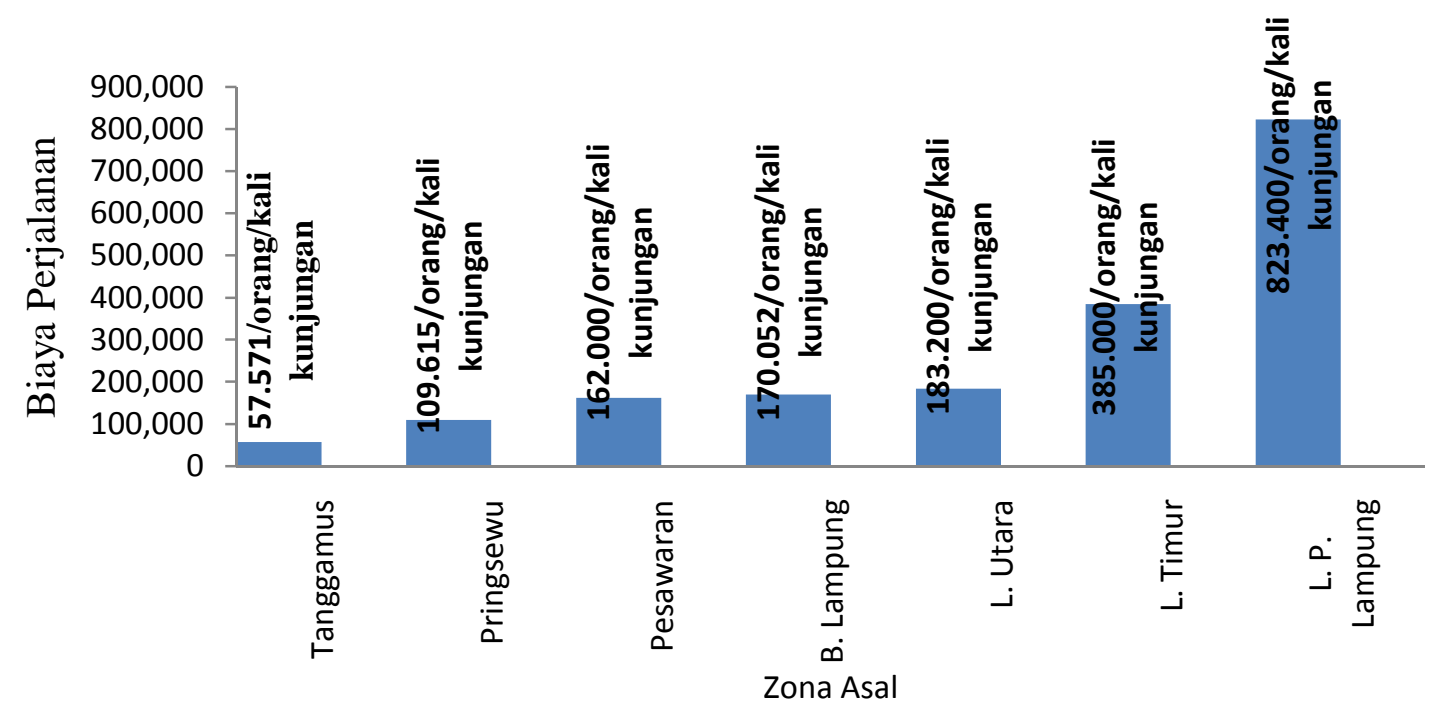

Gambar 1. Biaya perjalanan.

Besarnya biaya perjalanan

$$
\mathrm{BPT}=\mathrm{BTr}+\mathrm{BD}+(\mathrm{BKr}-\mathrm{BKh})+\mathrm{L}
$$

Keterangan :

$\mathrm{BPT}=$ Biaya perjalanan total (Rupiah/orang/hari)

$\mathrm{BTr}=$ Biaya transportasi dari tempat asal sampai ke tempat wisata (Rupiah/orang)

$\mathrm{BD}=$ Biaya dokumentasi (Rupiah/orang)

$\mathrm{BKr}=$ Biaya konsumsi selama rekreasi (Rupiah/orang/hari)

$\mathrm{BKh}=$ Biaya konsumsi tidak melakukan rekreasi(Rupiah/orang/hari)

$\mathrm{L} \quad=$ Biaya lain-lain (Rupiah/orang/hari)

Biaya rata-rata perjalanan pengunjung dapat dihitung berdasarkan rumus

$$
A T C=\sum \frac{B P T}{n}
$$

Keterangan :

ATC = Biaya rata-rata perjalanan pengunjung

$\mathrm{BPT}=$ Jumlah total biaya perjalanana pengunjung

$\mathrm{n} \quad=$ Jumlah pengunjung yang di wawancarai

Biaya perjalanan rata-rata per zona dihitung berdasarkan rumus sebagai berikut Safitri, dkk, (1996) :

$$
A T C i=\frac{\sum_{i=1}^{96} b P T j i}{N}
$$

Keterangan :

ATCi = Biaya perjalanan rata-rata dari zona $\mathrm{i}$ (rupiah/hari orang kunjungan)

BPTji = Jumlah total biaya perjalanan pengunjung ke-j dari zona $\mathrm{i}$ (rupiah/hari orang kunjungan )

$\mathrm{Ni} \quad=$ Jumlah total pengunjung dari zona i (orang) 
Nilai ekonomi objek wisata Air Terjun Way Lalaan dapat dihitung dari nilai rata-rata biaya perjalanan pengunjung dengan jumlah pengunjung selama 1tahun Sulistiyono, (2007) dalam Tambunan, (2013).

Berdasarkan penelitian, terdapat biaya pengunjung yang terbagi dalam 7 zona daerah asal berdasarkan wilayah administrasi pemerintah, seperti Kabupaten Tanggamus, Kabupaten Pesawaran, Kotamadya Bandar Lampung, Kabupaten Lampung Utara, Kabupaten Lampung Timur, Kabupaten Pringsewu, dan Luar Provinsi Lampung. Hasil penelitian tersebut diketahui biaya perjalanan pengunjung terbesar, berasal dari zona Luar Provinsi Lampung dengan rata- rata biaya orang/hari kunjungan sebesar Rp. 823.400,00/zona/kali kunjungan (5\%) dan yang paling kecil, berasal dari zona Tanggamus sebesar Rp. 57.571,00/zona/kali kunjungan (22\%). Berdasarkan hasil perhitungan, diperoleh nilai rekreasi Air terjun Way Lalaan sebesar Rp. 487.449.600/ Tahun.

\section{Variabel-Variabel yang Bepengaruh Terhadap Biaya Perjalanan}

Berdasarkan model persamaan yang telah dilakukan, diperoleh besar biaya perjalanan pengunjung sebesar Rp. 42.392//kali kunjungan. Hasil olahan data yang dilakukan terdapat beberapa variabel bebas (X) yang searah dengan variabel pengikat (Y) yang artinya peningkatan Rp.1 terhadap variabel $\mathrm{Y}$ sebagai variabel pengikat maka akan terjadi peningkatan terhadap variabel bebas. Salah satu contoh variabel Luar Kabupaten terdapat biaya perjalanan sebesar Rp.55.046 yang artinya setiap ada peningkatan Rp. 1 pada biaya perjalanan maka akan terjadi peningkatan pada zona Luar Kabupaten sebesar 55.046 /orang/kali kunjungan.

Selain dari variabel tersebut, terdapat juga beberapa variabel yang berbanding terbalik dengan biaya perjalanan, artinya setiap peningkatan Rp.1 pada variabel Y terjadi penurunan Rp.1 untuk variabel bebas. Salah satu contohnya status pernikahan terdapat biaya perjalanan yang -Rp. 305.398. Pada variabel ini biya perjalanan terdapat nilai minus yang artinya setiap ada peningkatan Rp. 1 pada biaya perjalanan maka akan terjadi penurunan sebesar -Rp. 305.398 /orang/kali kunjungan. Hal ini dapat diakibatkan oleh pengunjung yang lebih banyak masih belum menikah sehingga jumlah biaya yang dikeluarkan lebih sedikit. Hasil uji analisis regresi berganda dapat dilihat dalam bentuk tabulasi 3 .

Tabel 3. Variabel-variabel yang mempengaruhi biaya perjalanan.

\begin{tabular}{lllll}
\hline Predictor & Coef & SE Coef & T & P \\
\hline D1_L.KAB & 55046 & 42133 & 1,31 & 0,195 \\
D2-L.PROV & 726970 & 90975 & 7,99 & 0,000 \\
D3_PDPT & 50611 & 43718 & 1,16 & 0,250 \\
D4_SLTP & -44230 & 99888 & $-0,44$ & 0,659 \\
D5_SLTA & -23882 & 87475 & $-0,27$ & 0,786 \\
D6_PT & -22928 & 88814 & $-0,26$ & 0,797 \\
D7_umur & 6090 & 2940 & 2,07 & 0,042 \\
D8_MNKH & -305398 & 124155 & $-2,46$ & 0,016 \\
D9_PKRJ & -30387 & 37748 & $-0,80$ & 0,423 \\
D10_MOTIV & 23896 & 33813 & 0,71 & 0,482 \\
D11_TGGN & 367585 & 127928 & 2,87 & 0,005 \\
D12-KLMN & -61763 & 35320 & $-1,75$ & 0,084 \\
D13_WKT LG & 30838 & 35250 & 0,87 & 0,384 \\
D14_KNDRN & -87593 & 68987 & $-1,27$ & 0,208 \\
D15_JLH BKJNG & -43871 & 40342 & $-1,09$ & 0,280 \\
\hline Sum & & & &
\end{tabular}

Sumber :Hasil penelitian (2013). 
Koefisien atau parameter penduga dalam analisis regresi memiliki pengaruh yang berbeda pada tiap variabel bebas. Terdapat beberapa variabel yang berpengaruh nyata dan tidak nyata terhadap biaya perjalanan, diantaranya Luar Provinsi Lampung dengan nilai $\mathrm{P}=0,000=0 \%$ yang artinya zona luar provinsi lampung memiliki pengaruh yang sangat nyata dengan mengeluarkan biaya sebesar 7,99 dari zona dalam kabupaten. Umur memiliki pengaruh nyata $\mathrm{P}=0,042 \%=4,2 \%<5 \%$, yang artinya umur memiliki pengaruh yang sangat nyata sebesar 2,07 pada tiapa peningkata peningkatan 1 tahun.

Variabel lainnya adalah status pernikahan dengan nilai $\mathrm{P}=0,16 \%=1,6 \%<5 \%$ yang artinya status penikahan yang belum menikah memiliki pengaruh yang sangat nyata dengan mengeluarkan biaya sebesar -2,46 dibandingkan pengunjung yang sudah menikah. Variabel yang terakhir yang memiliki pengaruh nyata dengan biaya perjalanan adalah jumlah tanggungan dengan nilai $\mathrm{P}=0,005 \%=0,5 \%<5 \%$, artinya pengunjung yang belum mempunyai tanggungan memiliki pengaruh yang sangat nyata dengan mengeluarkan biaya sebesar 2,87 dibandingkan pengunjung yang sudah memiliki tanggungan.

Selain variabel tersebut, terdapat variabel zona luar kabupaten memiliki peluang $0,788=78,8 \%$ tidak berpengaruh nyata karena berpeluang untuk mengeluarkan biaya sebesar 0,27 kali dibandingkan dengan zona dalam kabupaten, pendapatan tinggi memiliki peluang $(0,250 \%=25 \%)$ tidak berpengaruh nyata dibandingkan pendapatan rendah. Pengaruh pendidikan SLTP $(0,659 \%=65,9 \%)$ tidak berpengaruh nyata $-0,44$ kali dibandingkan pendidikan SD, pendidikan SLTA $(0,786 \%=78,6 \%)$ tidak berpengaruh nyata $-0,27$ kali dibandingkan SLTP, pendidikan PT $(0,797 \%=79,7 \%)$ tidak berpengaruh nyata $-0,26$ kali dibandingkan pendidikan SLTA. Pengaruh pekerjaan $(0,423 \%=42,3 \%)$ tidak berpengaruh nyata $-0,80$ kali dibandingkan status pernikahan. Pengaruh motivasi $(0,482 \%=48,2 \%)$ tidak berpengaruh nyata 0,71 kali dibandingkan pekerjaan, pengaruh kelamin $(0,084 \%=8,4 \%)$ tidah berpengaruh nyata $-1,75$ kali dibandingkan dengan jumlah tanggungan. Pengaruh waktu luang $(0,384 \%=38,4 \%)$ tidah berpengaruh nyata 0,87 kali dibandingkan dengan jenis kelamin. Pengaruh kendaraan $(0,208 \%=20,8 \%)$ tidak berpengaruh nyata $-1,27$ kali dibandingkan dengan waktu luang. Pengaruh jumlah berkunjung $(0,280 \%=28 \%)$ tidak memiliki pengaruh nyata $-1,09$ kali dibandingkan dengan jenis kendaraan.

Besarnya nilai simpangan baku (S) pada analisis regresi tersebut adalah Rp.151.589 yang menyatakan jumlah sebaran paling banyak digunakan. Sedangkan besarnya pengaruh variabel dependen secara simultan atau bersama-sama (R-Sq) adalah 61,9\% dan R-Sq(adj) yang artinya besarnya naik turun pengaruh variabel tergantung korelasi variabel bebas yang ditambahkan pada suatu variabel terikat adalah sebesar 54,8\% sedangkan 45,2\% dipengaruhi oleh variabel-variabel lainnya.

\section{KESIMPULAN}

Nilai rekreasi air terjun Way Lalaan sebesar Rp. 487.449.600/ Tahun dengan persentase Karakteristik pengunjung, mayoritas pengunjung berasal dari kota Bandar Lampung sebesar $(50 \%)$ berjenis kelamin laki-laki $(68,75 \%)$, pengunjung merupakan persinggahan $(55,2 \%)$, dengan cara kelompok (51,04\%), motivasi kunjungan yaitu piknik $(77,08 \%)$, kelompok umur 20-29 (55,21\%), tingkat pendidikan $\operatorname{SLTA}(54,17 \%)$, pekerjaan adalah pegawai swasta (41\%), tingkat pendapatan >Rp. 1.500.000,00 (42\%), waktu luang terbesar adalah 2 hari (48\%), jumlah tanggungan belum ada (65\%), jenis kendaraan yaitu kendaraan pribadi (93\%).

Variabel yang berpengaruh nyata terhadap biaya perjalanan, diantaranya Luar Provinsi Lampung dengan nilai $\mathrm{P}=0,000=0 \%$ nilai parameter 726970 , umur memiliki pengaruh nyata $\mathrm{P}=0,042 \%=4,2 \%<5 \%$, nilai parameter sebesar 6090, status pernikahan dengan nilai $\mathrm{P}=0,16 \%=1,6 \%<5 \%$, nilai parameter yang diperoleh sebesar $-\mathrm{Rp}$. 305.398/ orang, jumlah tanggungan dengan nilai $\mathrm{P}=0,005 \%=0,5 \%<5 \%$, nilai parameter adalah Rp.367.585. Nilai $\mathrm{S}=$ 151589 dan nilai $\mathrm{R}(\mathrm{R}-\mathrm{Sq})$ adalah $61,9 \%$ dan $\mathrm{R}-\mathrm{Sq}(\operatorname{adj})$ adalah 54,8\%. 


\section{DAFTAR PUSTAKA}

Alam, S., Supratman., Alif, M. KS. 2009. Ekonomi Sumberdaya Hutan. Buku Ajar. Fakultas Kehutanan. Universitas Hasanuddin.

Eriyati., Indrawati, T., Anggreina J. 2010. Analisis valuasi ekonomi lingkungan kesediaan membayar masyarakat sekitar Sungai Siak. Jurnal Ekonomi. 18(1).

Fandeli, C dan Muklhlison. 2000. Pengusahaan Ekowisata. Buku. Pustaka Pelajar offset.

Hufschmidt, M.M., James, D.E., Meister, A.D., Bower, B.T., Dixon, J.A. 1996. Lingkungan, Sistem alami, dan Pembangunan. Pedoman Penilaian Ekonomis. Gadjah Mada University Press. Jogjakarta.

Rahmawaty, Pian, Z. A., Daulay, D, N, O. 2006. Analisis faktor-faktor yang mempengaruhi pengunjung agrowisata Taman Wisata Mekarsari dengan menggunakan metode kontingensi. Jurnal Usu Repository. Universitas Sumatera Utara.

Purwanto. 2013. Valuasi ekonomi ekowisata dengan model travel cost dan dampaknya terhadap usaha kecil pariwisata. Jurnal Manajemen Universitas W.R. Supratman. Surabaya. 15(1): 89-102.

Safitri, M., Siregar, H. Anwar, A dan Nasendi, B, D. 1996. Analisis wisata eko dan wisata budaya dengan metode kontingensi dan biaya perjalanan. Jurnal Majalah Duta Rimba. Hal: 5-6.

Silalahi, U.2008. Metode Penelitian Sosial. Buku. Refika Aditama.

Tambunan, A., Latifah, S., Pranata, P. 2013. Analisis nilai ekonomi obyek wisata alam di Kabupaten Samosir, Provinsi Sumatera Utara (studi kasus pemandian air panas di Kelurahan Siogung-ogung, Kecamatan Pangururan). Jurnal USU Repository. Universitas Sumatera Utara.

Trianita, R. 2011. Penilaian potensi wisata kawasan Muaro Silokek Durian Gadang sebagai alternatif pemanfaatan sumberdaya berkelanjutan. Skripsi. Fakultas Ekonomi dan Manajemen. Institut Pertanian Bogor. 